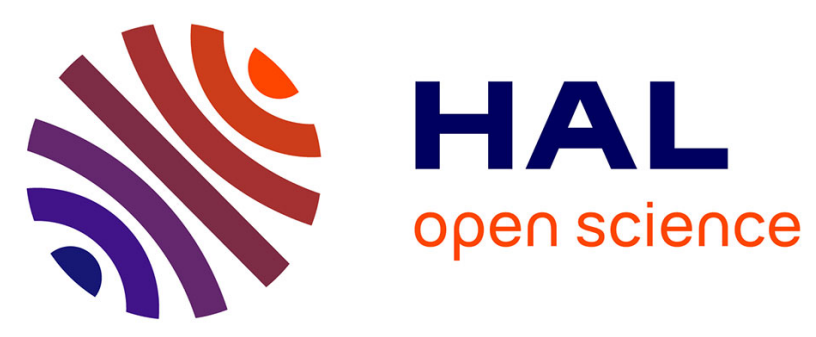

\title{
Pre-Neogene controls on present-day fault activity in the West Netherlands Basin and Roer Valley Rift System (southern Netherlands): role of variations in fault orientation in a uniform low-stress regime
}

Geza Worum, Laurent Michon, Ronald T van Balen, Jan Diederik van Wees, Sierd Cloetingh, Henk Pagnier

\section{To cite this version:}

Geza Worum, Laurent Michon, Ronald T van Balen, Jan Diederik van Wees, Sierd Cloetingh, et al.. Pre-Neogene controls on present-day fault activity in the West Netherlands Basin and Roer Valley Rift System (southern Netherlands): role of variations in fault orientation in a uniform low-stress regime. Quaternary Science Reviews, 2005, 24 (3-4), pp.475-490. 10.1016/j.quascirev.2004.02.020 . hal-01382029

\section{HAL Id: hal-01382029 \\ https://hal.univ-reunion.fr/hal-01382029}

Submitted on 14 Nov 2016

HAL is a multi-disciplinary open access archive for the deposit and dissemination of scientific research documents, whether they are published or not. The documents may come from teaching and research institutions in France or abroad, or from public or private research centers.
L'archive ouverte pluridisciplinaire HAL, est destinée au dépôt et à la diffusion de documents scientifiques de niveau recherche, publiés ou non, émanant des établissements d'enseignement et de recherche français ou étrangers, des laboratoires publics ou privés. 


\title{
Pre-Neogene controls on present-day fault activity in the West Netherlands Basin and Roer Valley Rift System (southern Netherlands): role of variations in fault orientation in a uniform low-stress regime
}

\author{
Geza Worum $^{\mathrm{a}, *}$, Laurent Michon ${ }^{\mathrm{b}}$, Ronald T. van Balen ${ }^{\mathrm{c}}$, Jan-Diederik van Wees ${ }^{\mathrm{d}}$, \\ Sierd Cloetingh $^{\mathrm{a}}$, Henk Pagnier ${ }^{\mathrm{d}}$ \\ ${ }^{a}$ Department of Tectonics, Vrije Universiteit, De Boelelaan 1085, $1081 \mathrm{HV}$ Amsterdam, The Netherlands \\ ${ }^{\mathrm{b}}$ Laboratoire des Sciences de la Terre, Université de la Réunion, 15 rue René Cassin, 97715 Saint Denis cedex 9, France \\ ${ }^{\mathrm{c}}$ Department of Quaternary Geology and Geomorphology, Vrije Universiteit, De Boelelaan 1085, 1081 HV Amsterdam, The Netherlands \\ ${ }^{\mathrm{d}}$ Department of Geo-Energy, TNO-NITG, Princetonlaan 6, 3508 TA Utrecht, The Netherlands
}

\begin{abstract}
The West Netherlands Basin (WNB) and the neighbouring Roer Valley Rift System (RVRS) form the most prominent tectonic features of the onshore Netherland s. The two basins have a common tectonic origin and similar Mesozoic evolution, their Neogene-Quaternary evolution, however, is marked lyd ifferent. While the WNB is tectonically/seismically inactive and is characterised by uniform Neogene-Quaternary subsidence, in the RVRS fault controlled intra-plate deformation has taken place since Late Oligocene times with pronounced seismic activity. Considering the present-day NE-SW regional extension as well as the similar basin orientation and Mesozoic evolutions one would not expect strikingly different neotectonic activity in the two basins. Detailedanalysis of Mesozoic, Tertiary andQuaternary fault patterns revealed that (1) the Palaeozoic-Mesozoic tectonic fabric has great influence on the Cenozoic d eformation style of the basin system; (2) present-d ay faulting in the RVRS is related to the reactivation of pre-existing faults and(3) the Mesozoic fault pattern is slightly different in the two basins. Using a novel technique (three-dimensional (3-D) slip tendency analysis) we aim to determine whether these differences in fault orientation are substantial enough to prod uce significantly different resolved stresses along the faults. This mod elling not only tests a common geological phenomena but indirectly also delivers important constraints regarding the origin of faulting in the study area. During the analysis 3-D geometric models of 84 mapped faults were investigated. The results of this recently developed modelling technique reveal that the faults in both basins should behave similarly und er the condition of a laterally homogeneous regional stress field, which is in disagreement with the present-day tectonic activity of the region. On the other hand the modelling also reveals that the predicted tend ency of slip is very sensitive to the ratio of the minimum horizontal and the vertical stress $(S)$. As an explanation for the pronouncedfault activity in the RVRS and the tectonic quietness of the WNB it is proposed that either the regional extension in the WNB is "weaker" (in term of higher $S$ ratio) than that in the RVRS or the slip thresholds in the two basins are different. The study emphasised that differentiation in the tectonic evolution has already started in the Tertiary, therefore, it is reasonable to assume that the different tectonic stress field and/or slip threshold between the two areas is directly related to the origin of the Cenozoic rifting in the RVRS. Several hypotheses are discussed to account for these two possibilities, taking into account the lithospheric structure and the Cenozoic tectonic evolution of the two basins as well as surrounding areas.
\end{abstract}

\footnotetext{
${ }^{*}$ Corresponding author. Tel.: + 31-20-4447374; fax: + 34-20-4449943.

E-mail address: geza.worum@falw.vu.nl (G. Worum).
} 


\section{Introduction}

The West Netherlands Basin (WNB) and the neighbouring Roer Valley Rift System (RVRS) form the most prominent geological features of the onshore Netherlands (Fig. 1). The basins are part of a $250 \mathrm{~km}$ long and $50 \mathrm{~km}$ wide Mesozoic basin system stretching in a NW-SE direction, which has been extensively studied in the past and is one of the geologically most explored areas of the Netherlands (e.g. Van Balen et al., 2000; Michon et al., 2003).

The present-day tectonic activity of the RVRS and WNB is markedly different despite their common tectonic origin and Mesozoic evolution. The seismic record of the last 100 years and numerous geological, morphological and geophysical studies indicate that the RVRS is currently characterised by ongoing, faultcontrolled intra-plate deformation (e.g. Groenewoud et al., 1991; Camelbeeck et al., 1994; Van den Berg, 1994; Ziegler, 1994; Kooi et al., 1998; Houtgast and Van Balen, 2000; Michon et al., 2003; Michon and Van Balen, this issue; Van Balen et al., 2004). Faults and tectonic basement blocks of Mesozoic and Palaeozoic origin play a major role in the neotectonic activity of this region. In contrast, the WNB area was in the Neogene-Quaternary characterised by a uniformly distributed, low amount of regional subsidence without abrupt changes in sediment thickness (Zagwijn, 1989; Kooi et al., 1998, De Mulder et al., 2003). In addition,

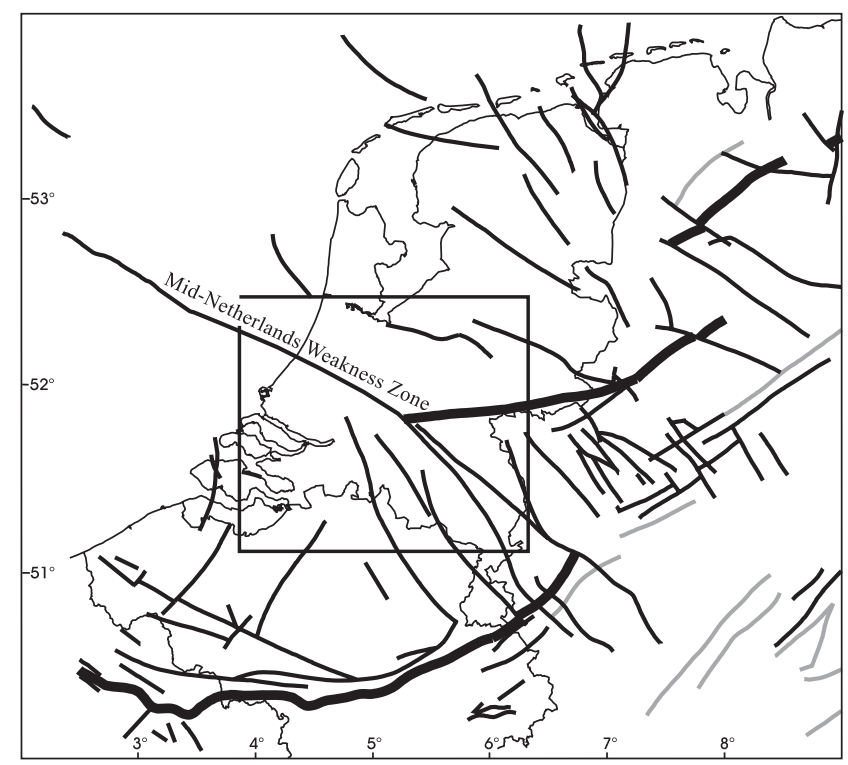

(a)

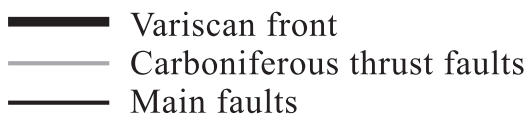

there are no geomorphic indications for fault activity and the area is seismically quiet.

In this paper, the present-day tectonics and fault behaviour of the WNB and the RVRS are compared and modelled using the three-dimensional (3-D) pretertiary fault pattern of the two basins. The structural analysis of the two basins reveals slightly different fault orientations in the WNB than in the RVRS. Using a novel technique (3-D slip tendency analysis, Worum et al., 2004) we aim to determine whether-assuming a uniform regional stress field - these differences in fault orientation are substantial enough to produce significantly different resolved stresses along the faults.

In order to better understand and explain the modelling results and the observed differences in neotectonic behaviour it is essential to discuss the preQuaternary basin evolution prior to the modelling. This is done in the first part of this paper, and delivers important constraints regarding the origin of the present-day tectonic movements in the RVRS. Then a detailed fault orientation analysis is performed comparing the Mesozoic, Tertiary and present-day fault patterns in the basin system. This analysis reveals slightly different Mesozoic fault orientations between the two basins as well as the great influence of ancient tectonic orientations on the Tertiary and present-day deformation of the basins. Finally, the slip tendency analysis is performed using the 3-D geometry of the fault systems. The results are discussed in light of the

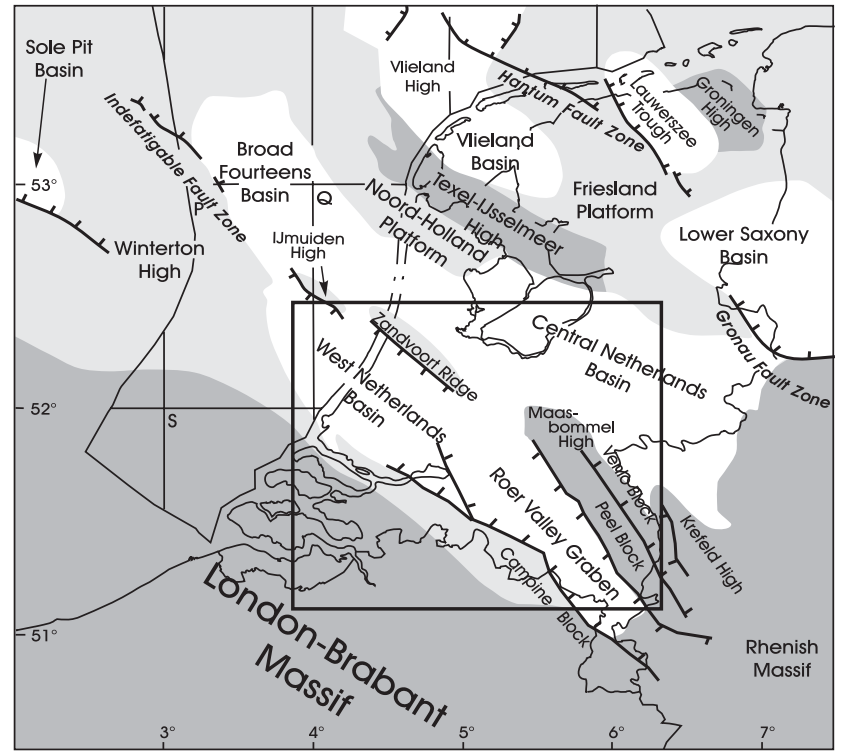

(b)

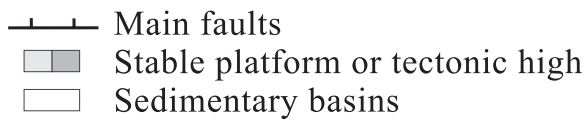

Fig. 1. Main tectonic features of the Netherlands and its surroundings after the Variscan orogeny (a) and in the Mesozoic (b) (modified after Lokhorst, 1998; TNO-NITG, 2002). Box indicates the study area. 
pre-Quaternary evolution of the basin system. Possible processes and tectonic models, which could explain the observed neotectonic differences are also discussed.

\section{Tectonic setting and basin evolution}

Due to differences in the sedimentary record and in the already mentioned neotectonic activity, the two basins were always treated as separate tectonic units, despite the fact, that they have a common tectonic origin and Mesozoic evolution. It is generally accepted that the WNB and the central trough of the RVRS (Roer Valley Graben (RVG)) are superimposed on an ancient tectonic lineament, which was formed due to wrench movements after the Late Carboniferous-Early Permian Variscan orogeny (e.g., Ziegler, 1990; Michon et al., 2003; Fig. 1a). In addition, study of the Campine Basin (part of the Carboniferous Variscan foredeep and "ancestor" of the Mesozoic WNB-RVG system) indicates an even older origin (Langanaeker, 1998; TNONITG, 2002). From now on we refer to this deep crustal lineament as the Mid-Netherlands Weakness Zone, which is located in the centre of the basin system, as indicated by earthquake epicentres. The Mid-Netherlands Weakness Zone is not to be confused with the Mid-Netherlands Fault Zone (e.g. TNO-NITG, 2002), which is the subsurface manifestation of the former. The Mid-Netherlands Fault Zone came into existence during the Mesozoic and forms the north-eastern boundary of the basin system. Several uplifted tectonic blocks are associated with this fault zone such as the IJmuiden High, the Zandvoort Ridge, the Maasbommel High and the Peel Block (Fig. 1b). In the SW, the basin system

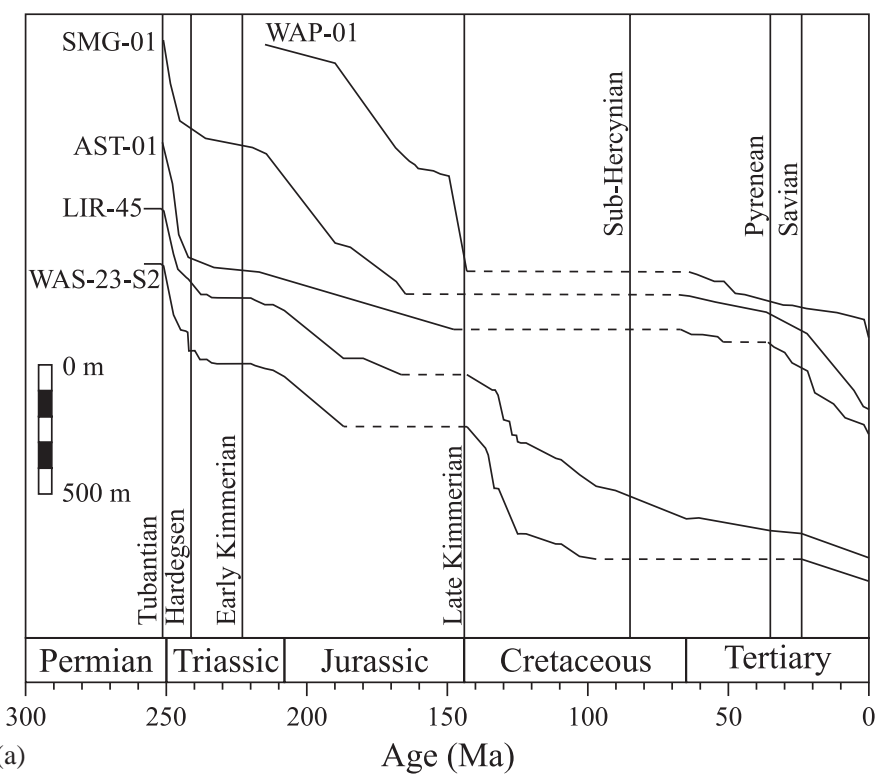

is also bounded by a tectonic high, namely the tectonically stable London-Brabant Massif of Variscan origin.

The evolution of the WNB-RVRS basin system is illustrated by the tectonic subsidence curves of 5 representative wells (Fig. 2). The curves provide the tectonic component of the total observed subsidence after removing the effect of compaction of the sedimentary column and the isostatic response of the lithosphere due to the sediment load. The backstripping analysis was carried out by Van Balen et al. (2000) (Lir-45 and Was-23-S2 wells) and Zijerveld et al. (1992) (Wap-1, Smg-1 and Ast-1 wells).

\subsection{Mesozoic}

The Mesozoic evolution of the WNB-RVRS system is characterised by multiple rifting phases induced mainly by the opening of the Tethys and the North Atlantic oceans (e.g. Ziegler, 1990). Of these the Late Permian, Late Triassic and Late Jurassic-Early Cretaceous rifting phases are the most important (Fig. 2a). The deformation phases during these periods induced differential subsidence and created several sub-basins in the area (Fig. 3), with the margins of the basin system being significantly uplifted (Van Wijhe, 1987; Ziegler, 1990; Geluk et al., 1994).

Fig. 3 indicates that the shape of the axis of the Mesozoic WNB-RVG basin system (slightly curved) coincides with the shape of the Mid-Netherlands Weakness Zone (see Fig. 1a). This suggests that the underlying tectonic fabric (Mid-Netherlands Weakness Zone) directly controlled the shape and location of the basin system during the Mesozoic.

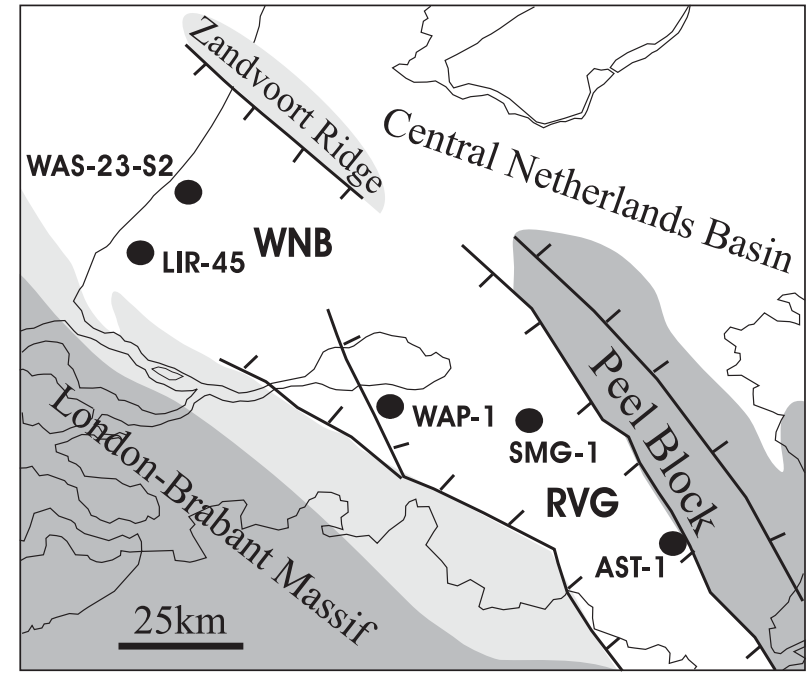

(b)

Fig. 2. (a) Tectonic subsidence curves of 5 representative wells located in the WNB-RVG system. (b) Location of the wells (after Zijerveld et al., 1992; Van Balen et al., 2000). 


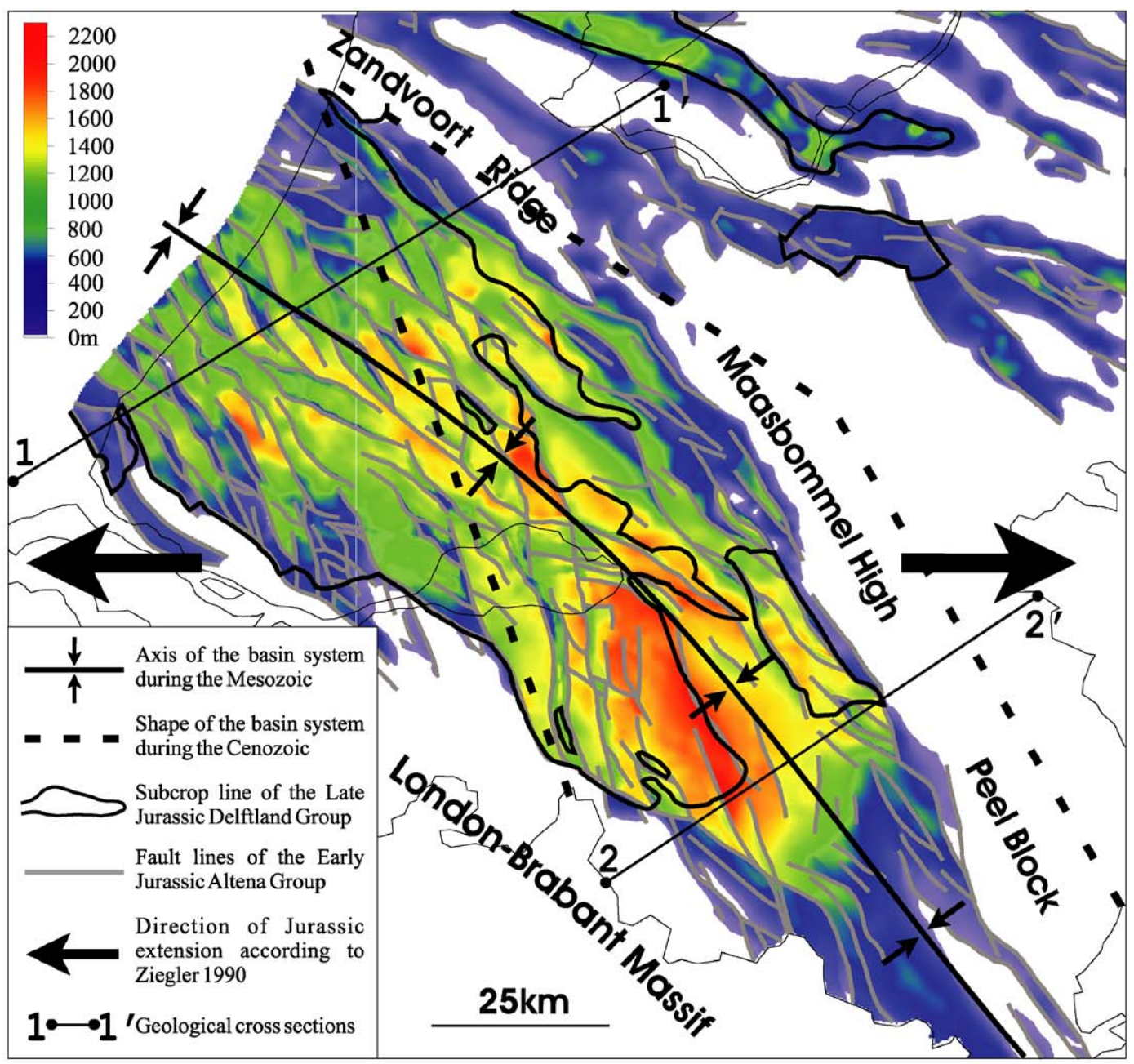

(a)
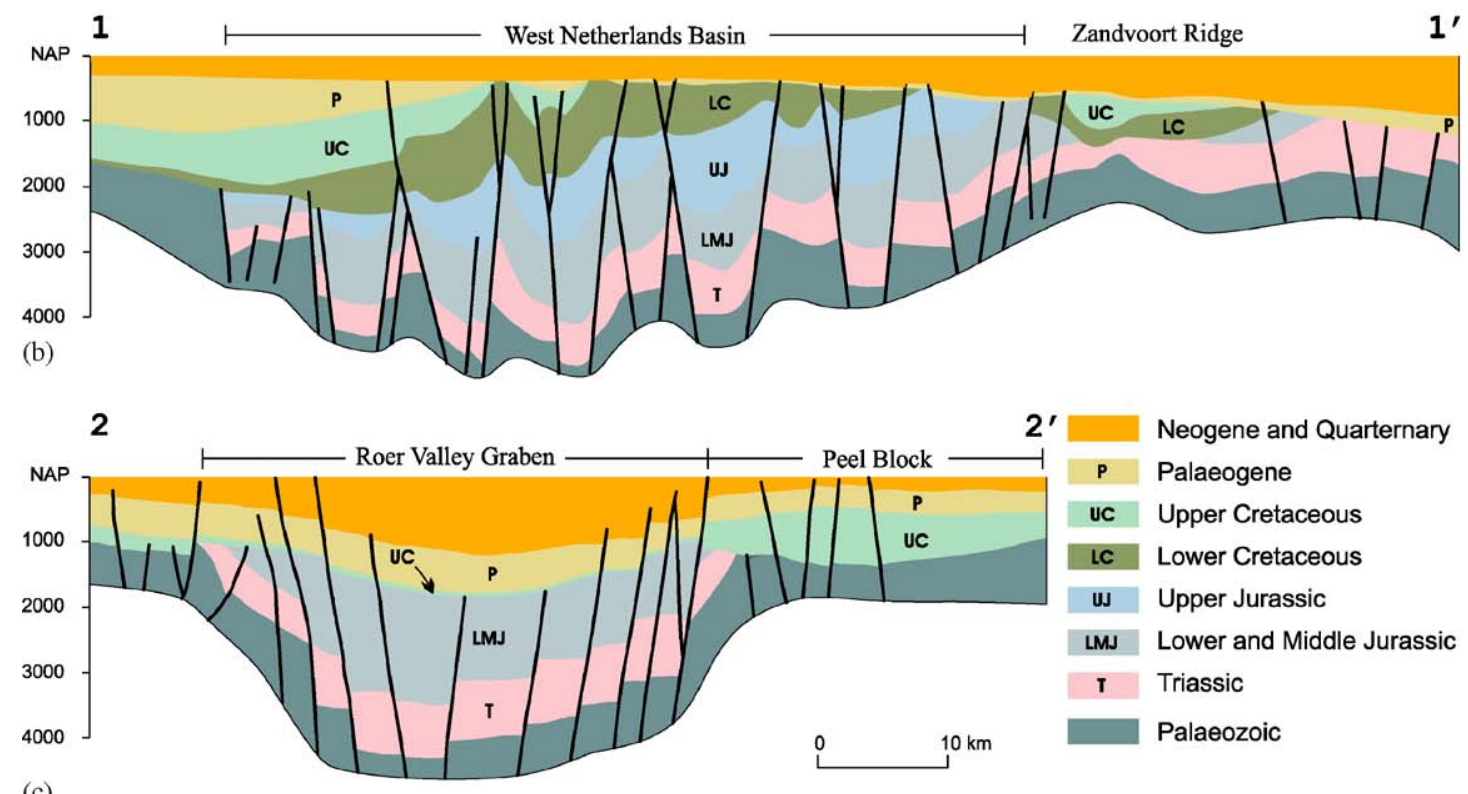

(c)

Fig. 3. (a) Thickness map of the lower Jurassic Altena Group. (b) Geological cross sections of the WNB and the RVG (after TNO-NITG, 1999, 2001, 2002, 2003; De Mulder et al., 2003). 
The characteristics of the subsidence curves (Fig. 2a) and the Jurassic subsidence pattern (Fig. 3a) reveal that the WNB-RVG basin system formed a single tectonic unity during the Mesozoic. These figures show that (1) the main tectonic phases were coeval in both basins, and (2) the resulting deformation is in agreement with the deformation expected from the proposed $\mathrm{E}-\mathrm{W}$ extension during the Mesozoic (Ziegler, 1990). Considering the regional scale orientation of the Mid-Netherlands Weakness Zone and the basin system, in the RVG, where the weakened zone is more perpendicular to an $\mathrm{E}-\mathrm{W}$ extension, the tectonic forces have resulted in a narrow, concentrated zone of deformation controlled by $\sim$ NNW-oriented faults. The orientation of these normal faults is consistent with the $\mathrm{E}-\mathrm{W}$ extension. In the WNB, where the orientation of the Mid-Netherlands Weakness Zone is more oblique to the direction of extension, transtensional deformation occurred. The distribution of deep, elongated sub-basins concentrated along WNW-oriented faults reflects this.

The subsiding period of the Mesozoic evolution ended in the Late Cretaceous-Early Palaeocene when compressive forces originating from the Euro-African collision inverted both the WNB and the RVG (SubHercynian and Laramide phases). Sedimentation continued during the Late Cretaceous-Early Palaeocene inversion phases on the former tectonic highs north and south of the basin system, while the former depocentres were deeply eroded (dashed lines in Fig. 2; Van Wijhe, 1987; Ziegler, 1990; Geluk et al., 1994; Gras and Geluk, 1999).

\subsection{Tertiary}

After the Early Palaeocene Laramide inversion phase the tectonic evolution of the WNB and the RVRS became very different. While the former WNB was characterised by continuous uplift during the Eocene and became a stable tectonic high (Letsch and Sissingh, 1983; Zagwijn, 1989; Worum and Michon, 2004), in the RVRS gentle regional subsidence occurred (see Fig. 2, Michon et al., 2003). The Eocene subsidence in the RVRS was not fault controlled and is proposed to be related to the thermal contraction of the lithosphere after the Early Cretaceous rifting, or to the elastic relaxation of the lithosphere following the Late Cretaceous inversion (De Lugt et al., 2003; Michon et al., 2003).

From the Late Oligocene onwards the differences between the two areas increased (Fig. 4). The WNB remained a tectonic high, as recorded by the OligoceneMiocene sediment thickness not exceeding $\sim 100 \mathrm{~m}$. In contrast, the RVRS restarted to subside and became a major Neogene-Quaternary depocentre as part of the NW European rift system (Letsch and Sissingh, 1983; Zagwijn, 1989; Ziegler, 1990, 1994; Geluk et al., 1994;
Michon et al., 2003). Comparison of the Neogene and Jurassic thickness maps reveals that the main Neogene depocentre in the RVRS is superimposed onto the Jurassic depocentre. This indicates the influence of older structures in the Cenozoic structural development.

It is important to note that the curved shape of the basin system in the Mesozoic significantly changed in the Tertiary. The dashed lines in Fig. 4 mark the area within the basin system where differential subsidence can be observed during the Neogene. The shape of this zone is lensoid and strongly controlled by the southwestern (i.e. Rijen fault and Feldbiss fault) and northeastern (Peel Boundary fault (PBF)) border faults of the RVG. This deformation zone is from now on referred to as the "extended" RVRS. In the WNB area no significant fault activity can be observed.

\subsection{Quaternary}

The tectonic style of the two areas remained different in the Quaternary. The few hundred meters of Quaternary subsidence in the WNB seems to be part of the general WNW directional tilting of the Netherlands caused by the flexural downwarping of the southern North Sea basin in response to the Plio-Quaternary sediment load and/or to the present day stress field (Zagwijn, 1989; Kooi et al., 1991). As indicated by the Quaternary sediment thickness distribution (Fig. 5, De Mulder et al., 2003) and the seismic quietness of the WNB, this subsidence was not accompanied by faulting.

In contrast, in the RVG the Quaternary subsidence continued to be strongly fault controlled (Geluk et al., 1994; Van den Berg, 1994; Van den Berg et al., 1994; Houtgast and Van Balen, 2000; Houtgast et al., 2002; Worum et al., 2004) and manifested itself in several significant earthquakes in the last century. In addition, in the RVRS the main Quaternary depocentre is superimposed onto the Neogene depocentre suggesting that the locus of ongoing sedimentation in the Quaternary is inherited from the Tertiary. Michon et al. (2003) showed however, that besides tectonics, compaction of the Tertiary sediments also significantly contributed to the Quaternary subsidence.

\section{Comparison of fault patterns}

Comparison of the Mesozoic, Tertiary and presentday fault patterns of the study area provides important constraints regarding the influence of older structures on the Cenozoic and present-day tectonic activity in the region. In addition, it might provide an explanation for the markedly different neotectonic behaviour in the two basins. 


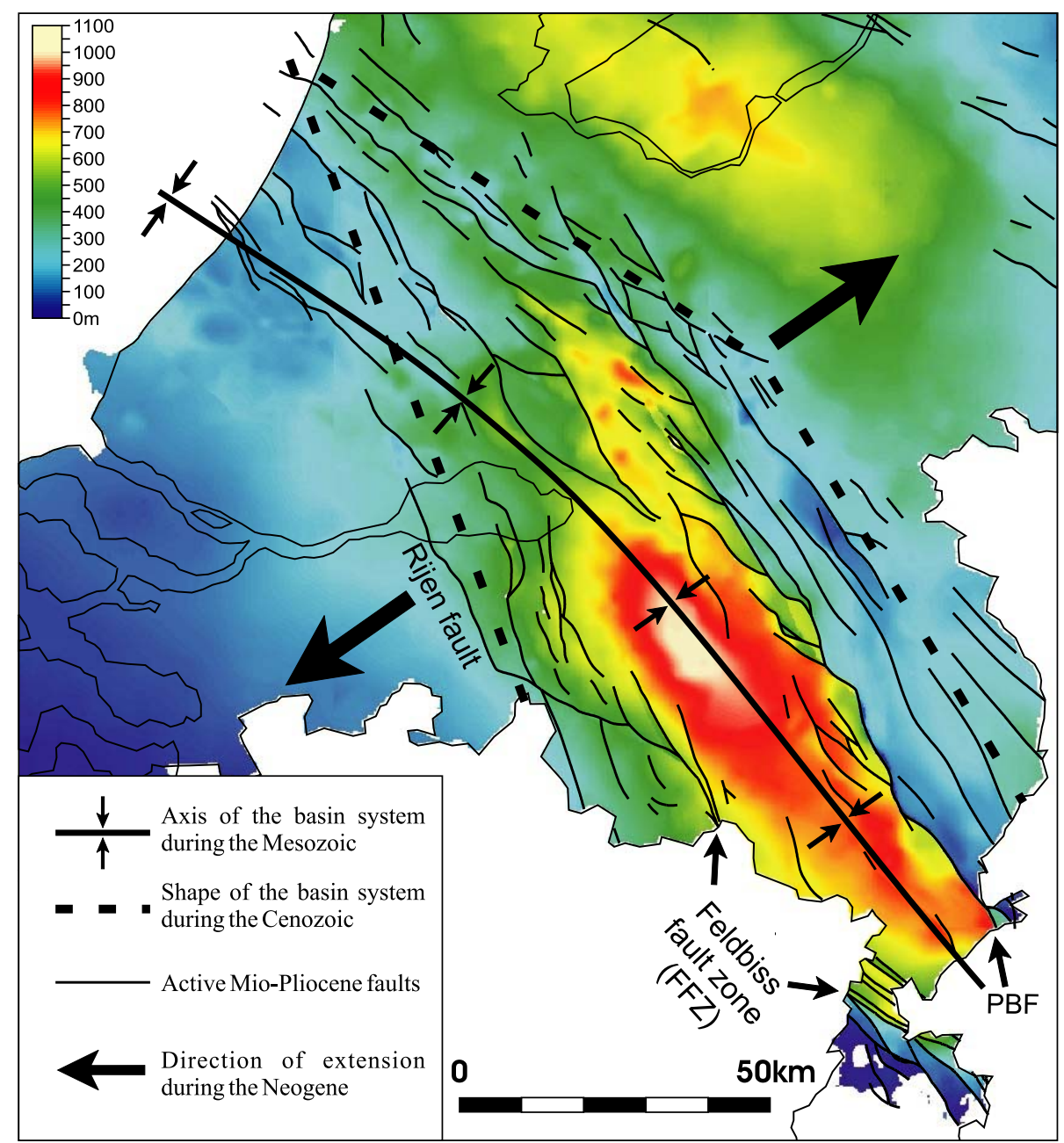

Fig. 4. Thickness and active fault map of the Neogene (PBF).

\subsection{Mesozoic fault pattern}

Fault lineaments incorporated in the analysis represent the active fault pattern during the Early-Middle Mesozoic. The input fault pattern was compiled from fault maps corresponding to various Mesozoic sedimentary units provided by the project "Geological atlas of the deep subsurface of the Netherlands" carried out at TNO-NITG Dutch Geological Survey (dinoloket.nitg.tno.nl). In the Belgian part of the study area, geological cross sections and maps published by Langanaeker (1998) were used.

Active faults were identified using thickness differences across fault lines. Due to later erosion, the distribution of the Mesozoic formations is non-uniform in the area. Therefore different sedimentary packages were used in various parts of the study area. Determination of the active fault pattern in the WNB and in the western part of the RVG was based on the thickness map of the Lower Jurassic Altena Group. In the eastern part of the RVG and north of the basin system the thickness map of the Triassic was used. In locations where the Triassic and Jurassic are both absent or deeply eroded (Zandvoort Ridge, Peel Block, SE corner of the Netherlands, Fig. 1) the Lower Cretaceous Rijnland Group or the Upper Cretaceous Chalk Group was used to identify the active faults.

During the analysis each fault line was divided into $250 \mathrm{~m}$ long segments and their orientation with respect to North was calculated. The subdivision makes it possible to take into account the fact that some faults consist of sections with different orientations. The results are presented in rose diagrams, where a bin size of 4 degrees is used.

The rose diagrams are calculated in 6 different regional domains (Fig. 6). Although the selected domains correspond to areas with different tectonic (fault) style, their boundaries are not clearly delimited by particular tectonic lines. The choice of the domains is based on clearly visible changes in the fault pattern.

Since domains C-F cover the area of interest these will be presented and discussed. Detailed discussion 


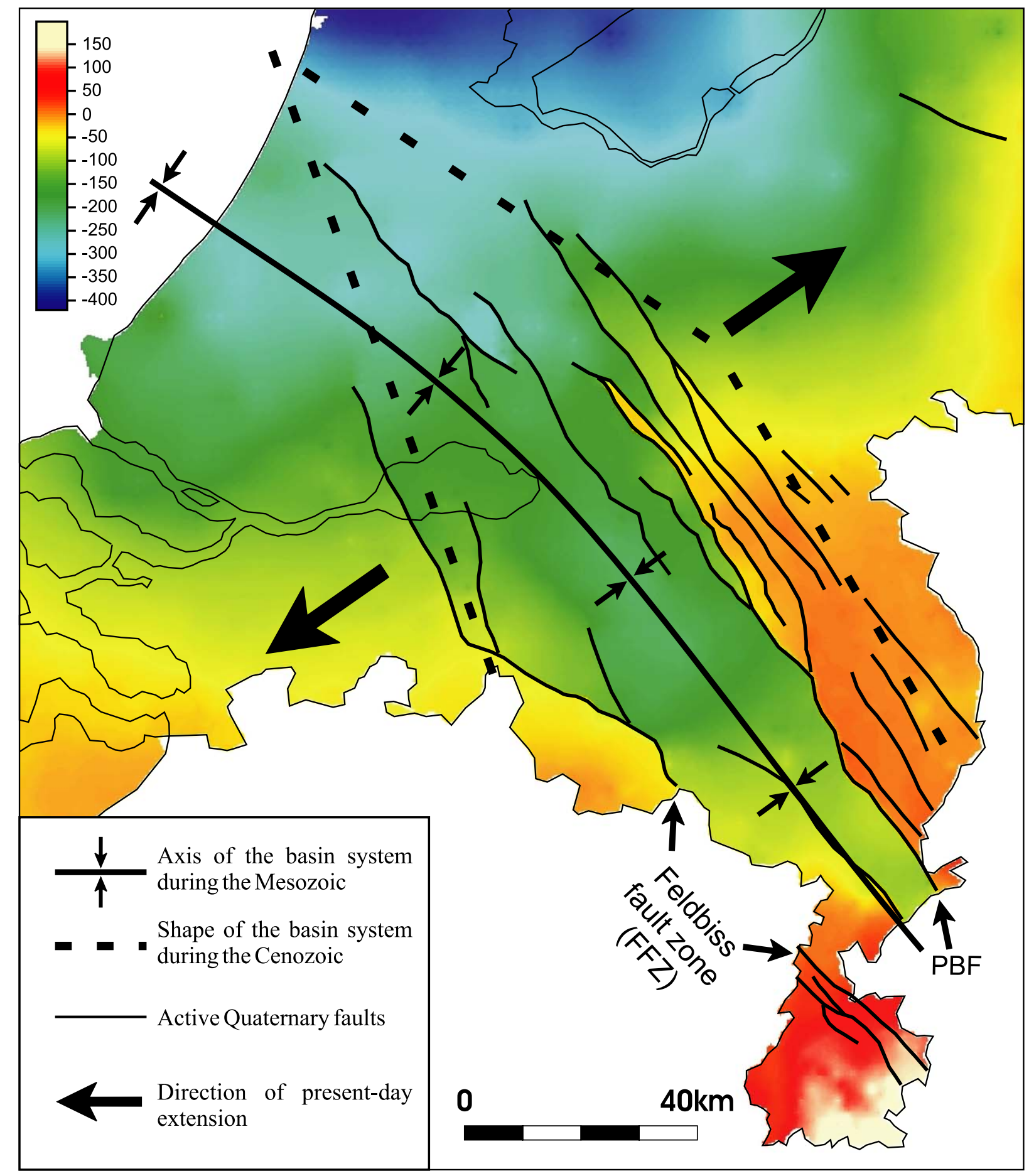

Fig. 5. Depth map of the base Quaternary horizon. Active Quaternary faults are indicated (PBF).

about domains $\mathrm{A}$ and $\mathrm{B}$ are beyond the scope of this paper, however, it is worthwhile to note, that the fault pattern in domain $B$ is very different from that of the other domains.

Domains $\mathrm{C}$ and $\mathrm{F}$, which represent, respectively, the northern part of the RVRS and WNB as well as the tectonic highs north of the basin system (Zandvoort Ridge, Maasbommel High and Peel Block) have unidirectional fault distributions (Fig. 6). The dominant direction in domain $\mathrm{C}$ and domain $\mathrm{F}$ is, respectively, $\mathrm{N} 148^{\circ}$ and $\mathrm{N} 130^{\circ}$. Thus, a $\sim 20^{\circ}$ of counter-clockwise rotation of the fault direction can be observed from domains $\mathrm{C}$ to $\mathrm{F}$. Rotation of the main fault directionalthough with less magnitude - can also be observed between domain $\mathrm{D}$ and $\mathrm{E}\left(\mathrm{N} 162^{\circ}\right.$ and $\mathrm{N} 154^{\circ}$, respectively). It has to be emphasised that the fault pattern in 


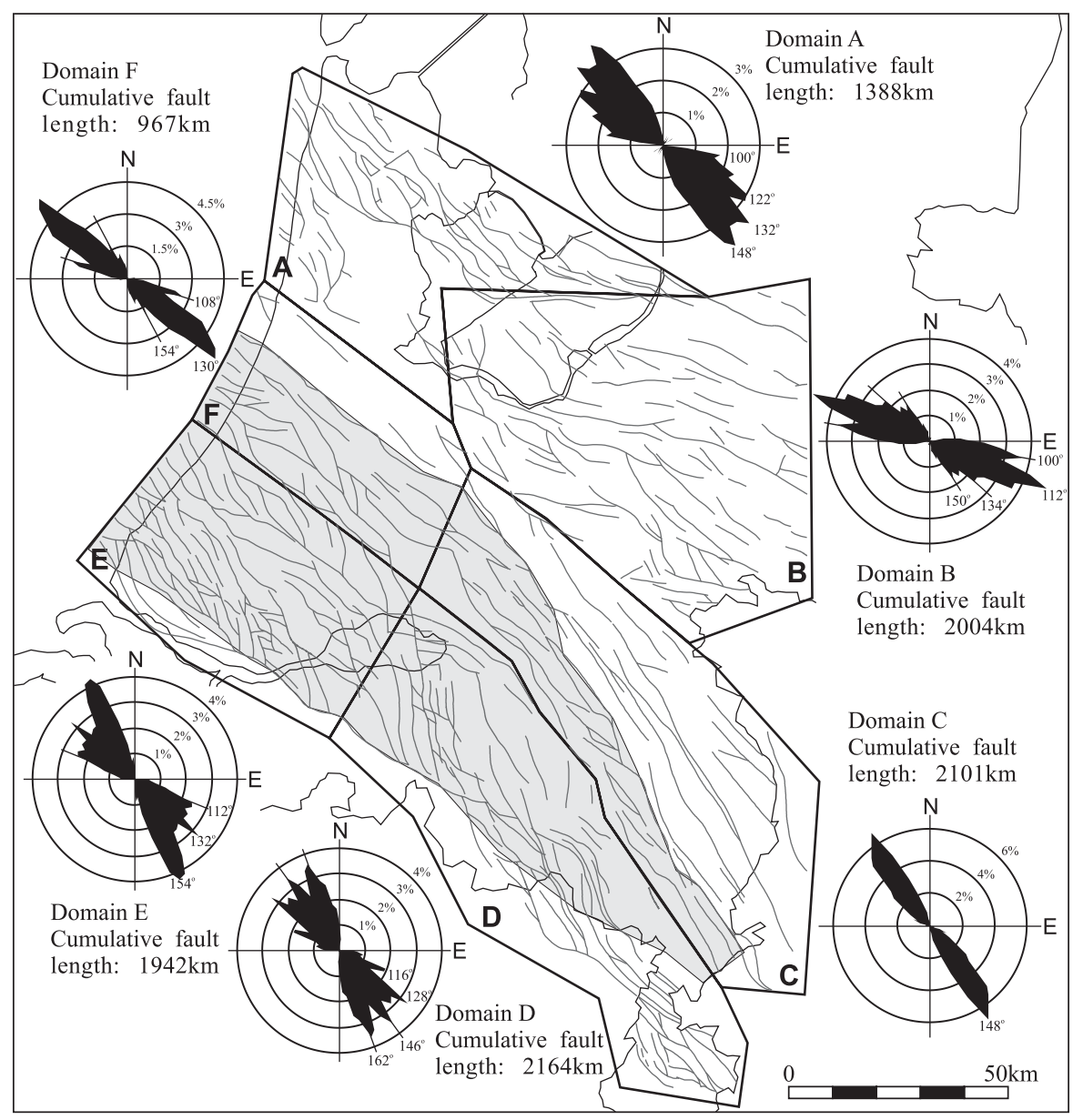

Fig. 6. Compiled map of the active Early-Middle Mesozoic faults (after TNO-NITG 1999, 2001, 2002, 2003). Background shading represents the outline of the WNB-RVG basin system (as in Fig. 3). Rose diagrams ( $\%$ of cumulative fault length/orientation) were calculated for different regional domains.

domains $\mathrm{C}$ and $\mathrm{F}$ is unidirectional. That is, in contrast to other domains, in domains $\mathrm{C}$ and $\mathrm{F}$ the Mesozoic deformational phases always created/reactivated, respectively, $\mathrm{N} 148^{\circ}$ - and $\mathrm{N} 130^{\circ}$-oriented faults, while faults with other orientations were not developed. This means that the $\mathrm{N} 148^{\circ}$ direction in domain $\mathrm{C}$ and the $\mathrm{N} 130^{\circ}$ direction in domain $\mathrm{F}$ represent fundamental preexisting lineaments, which are so weak that during the Mesozoic they were always reactivated before faults with other directions could have been created/reactivated.

Domains D and E correspond to the southern part of the WNB-RVRS basin system. In addition to the slight rotation of the main fault orientation from domain $\mathrm{D}$ to $\mathrm{E}$, it is also important to note that the N146-148 peak, which is present in domain $\mathrm{C}$ is also present in domain $\mathrm{D}$, but in domains $\mathrm{E}$ it is completely absent. In domain $\mathrm{C}$ the $\mathrm{N} 148^{\circ}$ orientation was attributed to pre-existing weak lineaments. It is suggested therefore that the presence of the $\mathrm{N} 148^{\circ}$ direction in domain $\mathrm{D}$ and its absence in domains $\mathrm{E}$ and $\mathrm{F}$ is related to the fact that the
$\mathrm{N} 148^{\circ}$ direction is indeed an inherited direction, specific only to the eastern part of the study area (RVRS).

In summary, the above fault patterns suggest that the southern and northern part of the study area represent different crustal domains (see also Michon et al., 2003). In the deeper parts of the crust the lineament, the MidNetherlands Weakness Zone, separating these fundamental crustal domains is located in the middle of the RVG and slightly north of the centre of the WNB. In the subsurface the Mid-Netherlands Weakness Zone manifested itself in a zone having a unidirectional fault pattern (i.e. Mid-Netherlands Fault Zone; domains C and $F$ ). This indicates the weak nature of this crustal segment compared to the other domains in the study area. The direction of the weakness zone changes between the RVRS and the WNB $\left(\sim 20^{\circ}\right.$ of counterclockwise rotation). As explained earlier and indicated by Fig. 3, the curved shape of the weakened zone directly controlled the shape of the developing basin system and the style of deformation in it during the Mesozoic. 


\subsection{Neogene-Quaternary}

The pattern of Neogene and Quaternary active faults is very similar, therefore they are discussed in the same section (Fig. 7). The overall Neogene fault pattern is dominated by the NW-oriented faults as indicated by the rose diagram in Fig. 7. Comparison of the orientation of the Neogene and Mesozoic faults reveals that the Neogene fault pattern is the result of the reactivation of faults already active during the Mesozoic. This indicates that Mesozoic structures strongly influenced the Cenozoic structural development. The primary fault direction in the Neogene is $\mathrm{N} 148^{\circ}$ reflecting the particular importance of this direction and/or a stable Neogene stress pattern in the long term. Another peak at $\mathrm{N} 138^{\circ}$, which was not present in the Mesozoic fault pattern is observed. The development of this fault direction could be explained by the upward rotation of the reactivated $\mathrm{N} 132^{\circ}$ and/or $\mathrm{N} 148^{\circ}$ Mesozoic faults in the thick Tertiary cover in order to accommodate the new stress field. The ancient $\mathrm{N} 132^{\circ}$ and $\mathrm{N} 155-160^{\circ}$ directions are also present in the "extended RVRS", but not in the rose diagram as main peaks. Despite their absence in the rose diagram as peaks, they play a major role at a regional scale as they correspond to the south-western and north-western limit of the "extended RVRS".

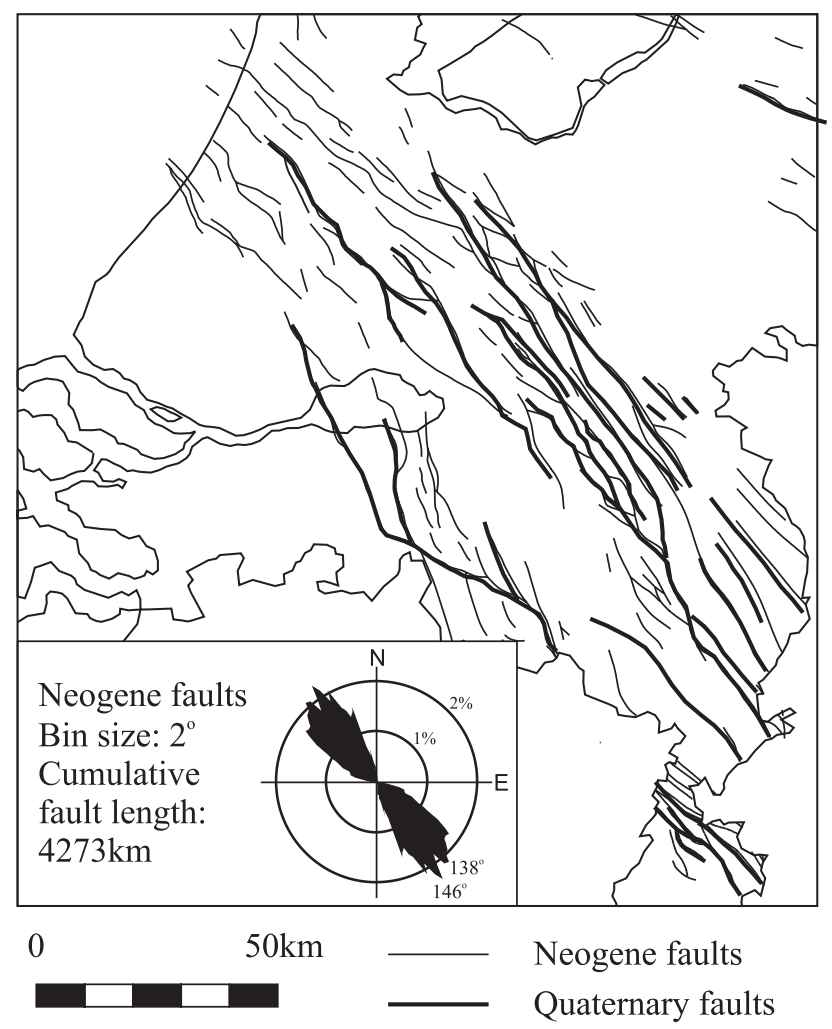

Fig. 7. Map of the active Neogene and Quaternary faults of the study area (after TNO-NITG, 1999, 2001, 2002, 2003; De Mulder et al., 2003). Inset: rose diagram of the Neogene fault pattern.
As Fig. 7 shows, in the area of the former WNB the Quaternary fault activity was limited to one fault in the northern part of the former basin. Other than that, there is no fault activity observed. In contrast, in the RVRS the Quaternary was characterised by significant faulting. The Quaternary fault pattern correlates well with the fault patterns of the Neogene or Mesozoic deposits (Fig. 6, see also Houtgast and Van Balen, 2000). This implies that the Quaternary and present day tectonics of the RVRS is to a great extent determined and still is being determined by older structures of PalaeozoicMesozoic origin.

\section{Neotectonic implications: slip tendency analysis}

As shown earlier, there are orientation differences in the Mesozoic fault pattern between the RVRS and the WNB. Due to these differences the faults in the two basins are expected to behave differently under conditions of a uniform regional stress, which could explain their markedly different Quaternary tectonic activity. In this section a newly developed technique (3-D slip tendency analysis) is used to investigate whether the observed fault orientation differences are substantial enough for the present-day tectonic stress field to produce significantly "weaker" resolved stresses along the faults in the WNB.

The approach developed by Worum et al. (2004) is used, which utilises the full 3-D fault geometry revealed by geological data to estimate the likelihood and style of fault reactivation. During the modeling, the parameters of slip tendency and shear direction are calculated at every location along a given fault represented by a 3-D triangulated surface. The 3-D fault models and the parameters describing the regional tectonic stress field serve as inputs for the method. The slip tendency is defined by the ratio of the resolved shear and normal stress magnitudes and is a useful parameter to constrain the likelihood of fault reactivation (i.e. tendency to slip: Morris et al., 1996; Worum et al., 2004). High slip tendency values indicate that the given fault is well oriented to the tectonic stress field and therefore suggests high probability of slip along the fault. During the calculation it is assumed that one regional stress tensor is responsible for the fault reactivation (i.e. Wallace-Bott hypothesis, Wallace, 1951; Bott, 1959), which is the same assumption as that used by the more popular stress inversion methods (e.g. Angelier, 1984; Gephart and Forsyth, 1984). In a dynamic way fault interactions, the rotation and deformation of the fault blocks, and the connectivity of some faults with deep crustal fractures are not taken into account. However, as Worum et al. (2004) demonstrated in the RVRS, as a first-order approximation the method is applicable to 
model the actual stresses on the faults and to constrain fault reactivation.

In order to adequately estimate fault reactivation with this method the frictional parameters along the faults have to be known. Due to lack of available data however, the exact slip threshold is difficult to determine. In addition, it can change from fault to fault and even along one particular fault. Fortunately, however, in the present study the exact value of a slip threshold is not needed, since we aim to determine whether slight differences in fault orientation between the WNB and the RVRS can cause significantly different slip tendencies in the same regional stress field. The slip tendency values of the faults of one basin, therefore, are simply compared to those of the other in order to determine which fault system is better aligned to the present day stress field.

\subsection{Input data}

Input data of the method consists of the 3-D geometrical fault models and parameters describing the confining stress field. In the present analysis fault models available from the database of TNO-NITG Dutch Geological Survey are used. Some of these models were also used by Worum et al. (2004), but those fault models, which were questioned by these authors (SE corner of the Netherlands, Limburg province) were not considered in the present analysis. Worum et al. (2004) also suggested that secondary faults closely located to primary faults having connections with deeper fractures cannot be considered as being independent regarding fault reactivation. Analysis of the 3-D geometrical fault database and seismic sections allowed us to select and exclude those dependent minor faults from the study. The remaining faults represent the first-order fault pattern, which plays a key role in the brittle deformation of the area (Fig. 8).

As stress indicators with high spatial density are not available in the study area stress tensors constrained by regional data have been used. The stress field is therefore assumed to be laterally homogeneous and linearly depth-dependent. It is also assumed, that the stress field is Andersonian, that is the observed maximum horizontal, minimum horizontal and vertical stresses represent the principal stresses. With respect to fault reactivation, the above stress field can be represented by a tensor having three independent parameters (Worum et al., 2004): the direction of $\sigma_{\mathrm{H}}$ as well as the $\sigma_{\mathrm{h}} / \sigma_{\mathrm{H}}$ and $\sigma_{\mathrm{v}} / \sigma_{\mathrm{H}}$ ratios, where $\sigma_{\mathrm{H}}, \sigma_{\mathrm{h}}$ and $\sigma_{\mathrm{v}}$ represent the maximum horizontal, the minimum horizontal and the vertical principal stresses, respectively.

The orientation and the principal stress ratios of the stress field were constrained by regional observations. $\sigma_{\mathrm{H}}$ directions were modelled as the two extremities of various observations (i.e. $\mathrm{N}_{145 \mathrm{E}^{\circ}}$ and $\mathrm{N} 160 \mathrm{E}^{\circ}$, e.g.

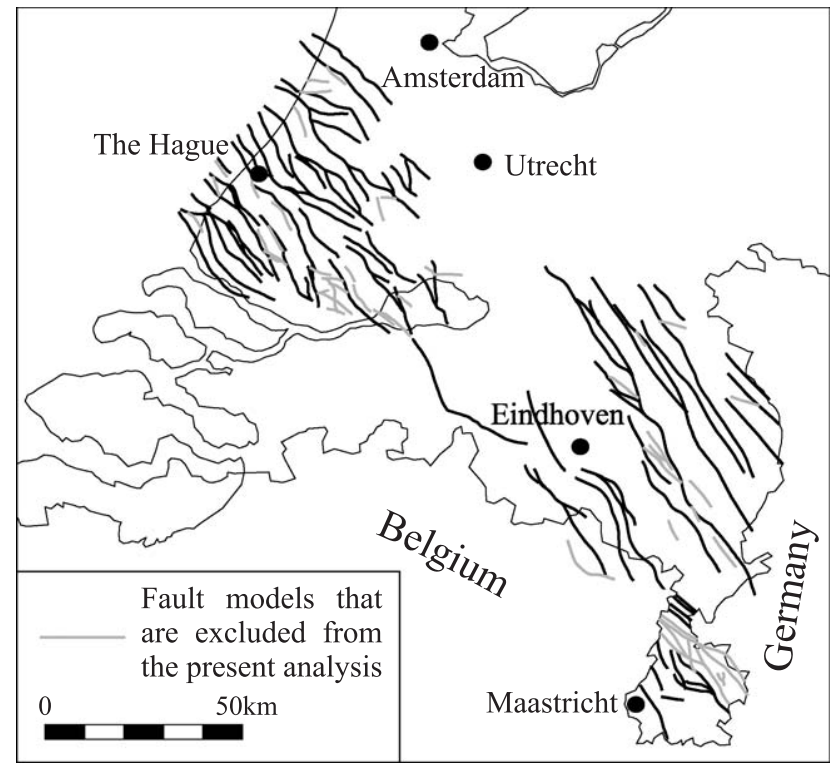

Fig. 8. Map-view representation of the available 3-D fault models in the study area. Fault models, which were excluded from the slip tendency analysis are indicated.

Bergerat, 1987; Müller et al., 1992; Rondeel and Everaars, 1993; Camelbeeck et al., 1994; Plenefisch and Bonjer, 1997; Michon et al., 2003). It is worthwhile to emphasise that both slip tendency and slip direction is a continuous function of the stress orientation. That it is sufficient to investigate the two extremities of the modelled $\sigma_{\mathrm{H}}$ direction interval, since intermediate orientations would not provide slip tendency and slip direction values out of the range represented by the two extremities.

The shape ratio of the input stress fields ( $\left.R=\left(\sigma_{2}-\sigma_{1}\right) /\left(\sigma_{3}-\sigma_{1}\right)\right)$ was kept $R=0.4$ in agreement with stress inversion results (Camelbeeck et al., 1994; Plenefisch and Bonjer, 1997). These studies have emphasised that an unequivocal distinction between a normal faulting and a strike-slip faulting stress regime was not possible. As Worum et al. (2004) demonstrated however, the present-day observed fault activity in the RVRS, using a reasonable range of stress ratios and slip thresholds can only be explained by normal faulting stress regimes $\left(\sigma_{\mathrm{v}} / \sigma_{\mathrm{H}} \sigma>1>\sigma_{\mathrm{h}} / \sigma_{\mathrm{H}}\right)$. In addition, recent morphological and geological studies also suggest that the normal faulting stress regime is more likely (Houtgast et al., 2002; Michon and Van Balen, 2004). In the present modelling therefore only this stress regime is considered.

As the faults are quasi parallel to the orientation of $\sigma_{\mathrm{H}}$, it is expected that the calculated slip tendencies are very sensitive to the $\sigma_{\mathrm{h}} / \sigma_{\mathrm{v}}$ ratio $(S)$. Therefore, in the modelled stress scenarios the $S$ ratio uniformly covers a wide range. This range was adopted for both stress orientations $\left(\sigma_{\mathrm{H}}=N 145^{\circ}\right.$ and $\left.\mathrm{N} 160^{\circ}\right)$, resulting altogether in 16 different stress scenarios (Table 1). 
Table 1

Stress ratio triplets of the various input stress tensors applied during the slip tendency analysis

\begin{tabular}{llllllll}
\hline$\sigma_{\mathrm{h}} / \sigma_{\mathrm{v}}$ & 0.2 & 0.3 & 0.4 & 0.5 & 0.6 & 0.7 & 0.9 \\
$\sigma_{\mathrm{v}} / \sigma_{\mathrm{H}}$ & 1.471 & 1.389 & 1.316 & 1.250 & 1.190 & 1.136 & 1.087 \\
$\sigma_{\mathrm{h}} / \sigma_{\mathrm{H}}$ & 0.294 & 0.417 & 0.526 & 0.625 & 0.714 & 0.795 & 0.938 \\
\hline
\end{tabular}

\subsection{Analysis of the calculated slip tendency patterns}

Due to the large number of input stress tensors, only a selection of the most instructive results is presented in the form of a 3-D perspective view (Fig. 9). It should be noted that on this figure only a $\sim 1500 \mathrm{~m}$ high strip in the centre of the faults is visualised. We did this in order to prevent the view of the faults from being obstructed by other faults. In reality the depth range of the faults is much larger. Concerning the modelled shear directions, first the averages of the shear direction pattern were calculated for every fault, which were later displayed as polar histograms. These histograms therefore provide information about shear directions regarding the whole fault population and not the individual faults. As the $R$ value of the input stress tensors was kept constant, the calculated patterns of shear directions are identical for every stress field having the same orientation (Fig. 9).

\subsubsection{Influence of $S$}

The results reveal that the calculated slip tendencies are very low for cases with $S \geqslant 0.6$. The very low slip tendency values suggest that all the faults would be likely locked in a stress field having an $S$ ratio higher than 0.6. As expected, with decreasing $S$ ratio the slip tendency increases, suggesting higher probability of slip (Fig. 9). One may note that there is no observable difference in fault behaviour in terms of average slip tendency between the WNB and the RVRS in any of the cases. This implies that fault pattern differences between the WNB and the RVRS are not large enough to result in markedly different slip tendencies. Fig. 9 shows on the other hand, that a rise of $S$ by 0.1 decreases the slip tendency by $0.1-0.15$. This will be discussed below.

\subsubsection{Influence of the $\sigma_{\mathrm{H}}$ direction}

Comparing slip tendency patterns related to stress fields having the same magnitude but different orientation reveals that the calculated slip tendencies are slightly lower when the direction of $\sigma_{\mathrm{H}}$ is $\mathrm{N} 160^{\circ}$ than when it is $\mathrm{N} 145^{\circ}$. The reason is that in case of a $\mathrm{N} 145^{\circ}$ orientation of $\sigma_{\mathrm{H}}$, the plane of the maximum and minimum principal stress $\left(\sigma_{\mathrm{h}}-\sigma_{\mathrm{v}}\right.$ plane $)$ is perpendicular to most of the faults, resulting in optimal orientation and therefore higher slip tendency. This effect however, is significantly less than that observed by changing the $S$ ratio.

The polar histograms of the average shear directions imply dip-slip shear forces along the faults. In case of an
$\mathrm{N} 145^{\circ}$ direction of $\sigma_{\mathrm{H}}$ there is a $0-10^{\circ}$ of oblique component in the shear direction. This value increases to $10-20^{\circ}$ in cases where the orientation of $\sigma_{\mathrm{H}}$ equals $\mathrm{N} 160^{\circ}$. Observations regarding the direction of slip along the main borderfaults of the RVRS show predominantly normal faulting behaviour, which does not disagree with the results of this study. Using earthquake focal mechanism data Camelbeeck et al. (1994) and Camelbeeck and Van Eck (1994) determined shear directions with only a minor oblique component. The morphological study of Michon and Van Balen (2004) on the other hand determined pure dip slip motions. In light of these observations a stress tensor with $\sigma_{\mathrm{H}}=N 145^{\circ}$ orientation is the most likely.

\subsection{Results of the slip tendency analysis}

The results of the slip tendency analysis reveal that due to the small difference in fault orientations the faults of the WNB and RVRS should behave almost identically in a uniform stress field. Among the different input stress tensors none could explain the observed neotectonic quietness in the WNB and the strong fault activity in the RVRS. On the other hand, the analysis revealed that a relatively small rise in the ratio of the minimum horizontal and the vertical principal stresses $(S)$ is enough to significantly decrease the calculated slip tendency. This slip tendency drop may be high enough to bring the slip tendency in the WNB below a given slip threshold. The analysis indicates therefore, that the observed fault activity in the RVRS and the coeval inactivity in the WNB can only be achieved if different stress fields and/or slip thresholds are assumed for the two areas.

\section{Discussion and conclusions}

Modelling the present-day reactivation of Mesozoic faults in the WNB and the RVRS under simple, laterally homogeneous stress fields predicts similar fault behaviour throughout the basin system. This is in disagreement with the observations, for which the explanation could be the possible differences in the state of stress and/or in the slip thresholds between the two areas. That is, there is either more extension in the RVRS in terms of lower $S$ ratio $\left(\sigma_{\mathrm{h}} / \sigma_{\mathrm{v}}\right)$, or/and the faults are easier to reactivate in the RVRS than in the WNB. These possible 


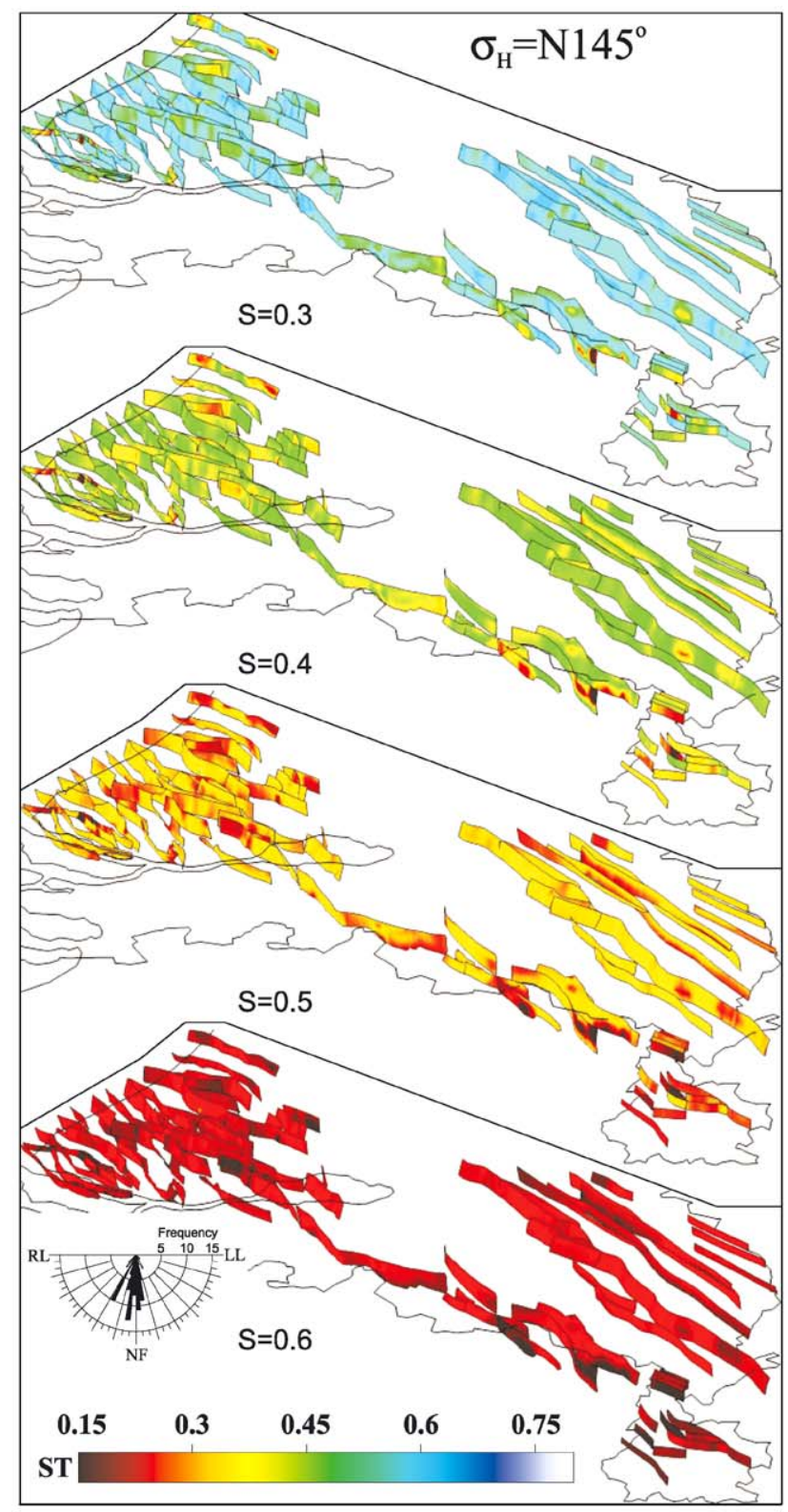

(a)

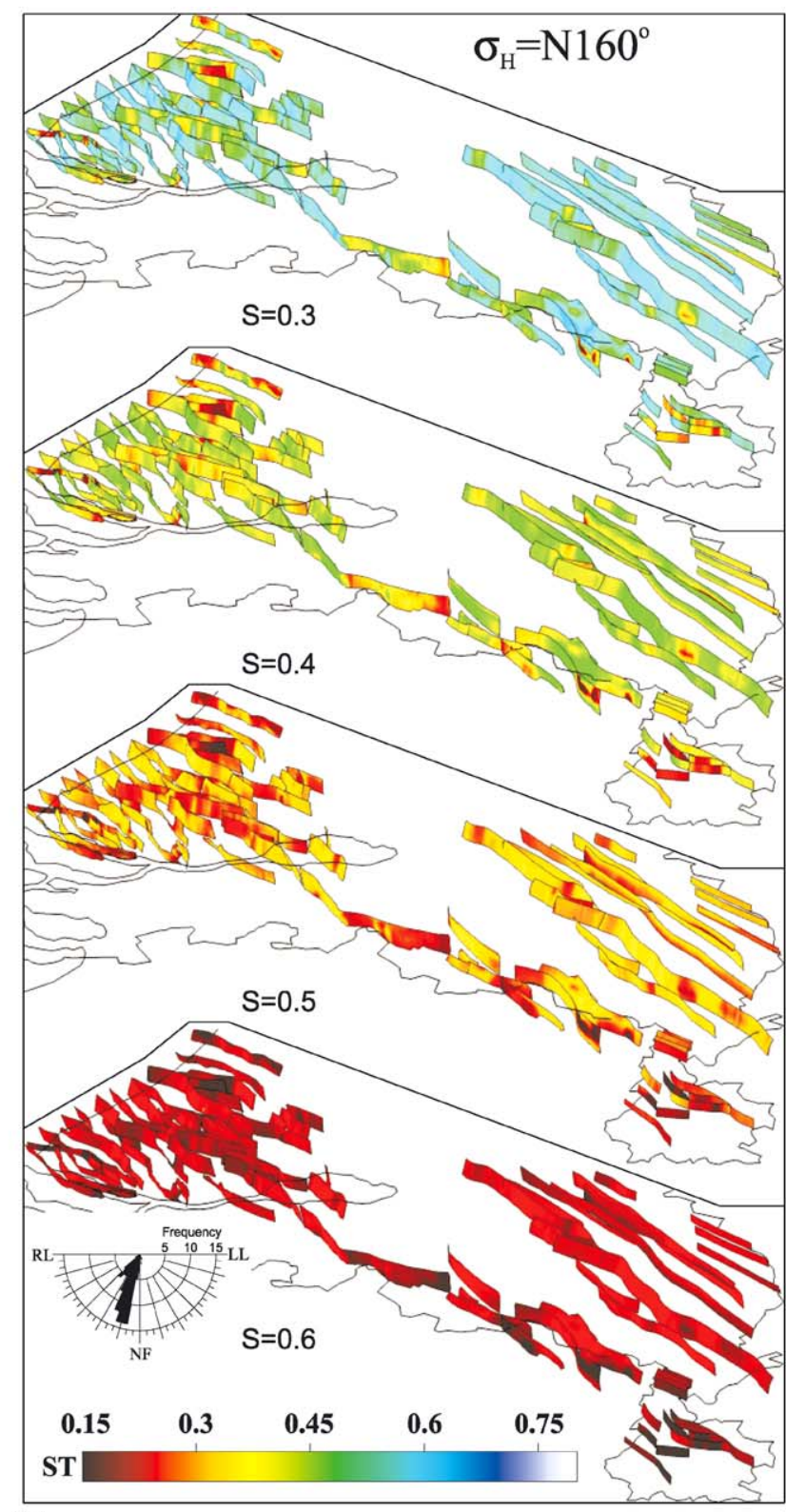

(b)

Fig. 9. Calculated 3-D slip tendency (ST) patterns of the modelled faults for different stress tensors having $\sigma_{\mathrm{H}}$ direction of (a) N145 $5^{\circ}$ and (b) $\mathrm{N} 160^{\circ}$. The polar histograms display the number of faults along which the average of the shear vectors point into the given direction. (NF $=$ normal faulting (dip slip); $\mathrm{LL}=$ left lateral slip; $\mathrm{RL}=$ right lateral slip; $S=\sigma_{\mathrm{h}} / \sigma_{\mathrm{v}}$ ).

differences are assumed to be responsible for the lack of Quaternary fault activity and the present-day seismic quietness in the WNB.

The study emphasised that differentiation in the tectonic evolution has already started in the Tertiary. Therefore, it is suggested that the different tectonic stress fields and/or slip thresholds between the two areas are directly related to the origin of the Cenozoic rifting in the RVRS. Several hypothesis are presented below, however, none is conclusive. Additional research is needed to better understand the origin of the RVRS and to put the southern Netherlands into a broader tectonic context. This research might also help in the future to find the reason why the neotectonic behaviour of the RVRS and the neighbouring WNB is so different from each other.

\subsection{Possible causes of different stress fields}

As the RVRS is part of the NW European Cenozoic Rift System, for an explanation of a possibly stronger present-day extension in this area relative to the WNB, 
the RVRS has to be put in a broader, NW European tectonic context. At a European scale there is a general consensus that the Late Eocene rifting in the southern Rhine Graben has propagated northward and breached the Rhenish Shield in a NW-SE direction during the Early Oligocene. The rift then propagated further to the NW and reached the RVRS area in the Middle-Late Oligocene (e.g. Ziegler, 1994). Mechanisms proposed so far to explain the formation of the NW European Rift System focus primarily on the development of the regional tectonic stress pattern in NW Europe as the primary source of the rifting (for a summary of these models see the discussion of Michon et al., 2003). These models did not explain why the rift did not propagate further to the WNB.

In search for an explanation of the possibly different stress fields, the deeper crustal and lithospheric configuration of the southern Netherlands also has to be taken into account. Unfortunately, there are no observations available regarding the lithospheric structure in this area. However, crustal seismic surveys show that both areas are characterised by a thinned crust, which is more pronounced in the RVRS (i.e. crustal thickness of around $28 \mathrm{~km})$ than in the WNB $(\sim 30 \mathrm{~km}$, Rijkers and Duin, 1994). A thinner and consequently weaker crust could cause higher stress magnitudes in the crust of the RVRS compared to that of the WNB. However, it still remains unclear why the Oligocene rifting, as the most probable cause of the additional thinning of the crust in the RVRS, did not propagate further into the WNB.

South of the RVRS, the Variscan Rhenish Massif is a neotectonically uplifted area. The uplift is coeval with the subsidence in the RVRS. In addition, paleomagnetic data presented by Schreiber and Rotsch (1998) indicate a $10-16^{\circ}$ clockwise rotation of the Eastern Rhenish Massif since the Late Oligocene, which is also coeval with the rifting in the Lower Rhine Graben (and in the RVRS). Thus, unravelling the tectonic relations between the Rhenish Massif and the RVRS may also explain the neotectonic differences between the RVRS and the WNB. Although the exact driving force of the rotation of the NE Rhenish Massif is still unknown (probably the NE-SW extension itself), it was proposed that it is directly responsible for the Vshaped opening of the Lower Rhine Graben and for the rifting in the RVRS (Illies and Fuchs, 1983; Schreiber and Rotsch, 1998). Considering the hypothesis that the rotation of the NE Rhenish Massif generated additional extension in the Lower Rhine Graben, a transfer zone in the NW part of the rotating block has to be assumed in order to explain the rifting not stepping into the WNB. As illustrated by Fig. 10, in such a scenario $\sim$ NE-oriented faults of Variscan origin can play the role of a transfer zone. However, it has not yet been recognized that these faults acted as transfer faults during the Neogene.
Geophysical surveys as well as teleseismic tomography results show a pronounced column-like mantle structure below the Rhenish Massif extending to at least $400 \mathrm{~km}$ depth (Fig. 10, e.g. Prodehl et al., 1992; Ritter et al., 2001). Various field and modelling studies indicated that this mantle feature is very young ( $\sim 1 \mathrm{Ma}$, e.g. Lippolt, 1983; Garcia-Castellanos et al., 2000) and that it has not (yet) produced a corresponding surface heat flow signal (Haenel, 1983). The plume is not wide enough $(\sim 100 \mathrm{~km})$ to affect the mantle part of the lithosphere below the RVRS and in addition, its emplacement post-dates the initiation of the main rifting.

The geological record on the other hand shows that there was an earlier volcanic activity at the same location well before the emplacement of the later plume (e.g. Huckenholz, 1983; Lippolt, 1983). This volcanism is coeval with or slightly pre-dates the rifting episode. These older volcanites reached the surface along preexisting fractures, which orientation seem to coincide with the orientation of the Lower Rhine Graben and the RVRS (e.g. Schreiber and Rotsch, 1998). The cause of this volcanism is still unclear. However, it is speculated that it might be related to a mantle anomaly (see also Huckenholz, 1983), from which the later plume developed. This swell must have been much more gentle and wider than the present-day plume and might have existed already during the onset of rifting. A thermal anomaly in the lithosphere due to elevated heat flow was determined as being one of the possible explanations for high intra-plate seismicity in the New Madrid seismic zone (Central USA, Liu and Zoback, 1997). In thermally perturbed areas due to the higher temperature the bulk strength of the upper mantle is significantly reduced resulting in concentrated and higher tectonic stresses in the upper crust compared to those areas, which are thermally not perturbed. Unfortunately this model cannot be confirmed in the study area, since available subsurface temperature and heat flow data is sparse in the southern Netherlands. In addition heat flow calculations were based on significant simplifications, which presents an obstacle to reliable and detailed thermal comparisons between the RVRS and WNB (Ramaekers, 1991; Van Balen et al., 2002).

\subsection{Possible causes of different slip thresholds}

It was shown by analogue experiments that repeated reactivation reduces the frictional parameters of faults, most probably by the development of a subsequently thicker gauge layer (e.g. Krantz, 1991). It can be proposed therefore, that the Oligocene rifting in the RVRS decreased the slip threshold in the RVRS along the primary faults. In contrast, in the WNB, where the Oligocene rifting was absent, the slip threshold did not decrease. However, significant 


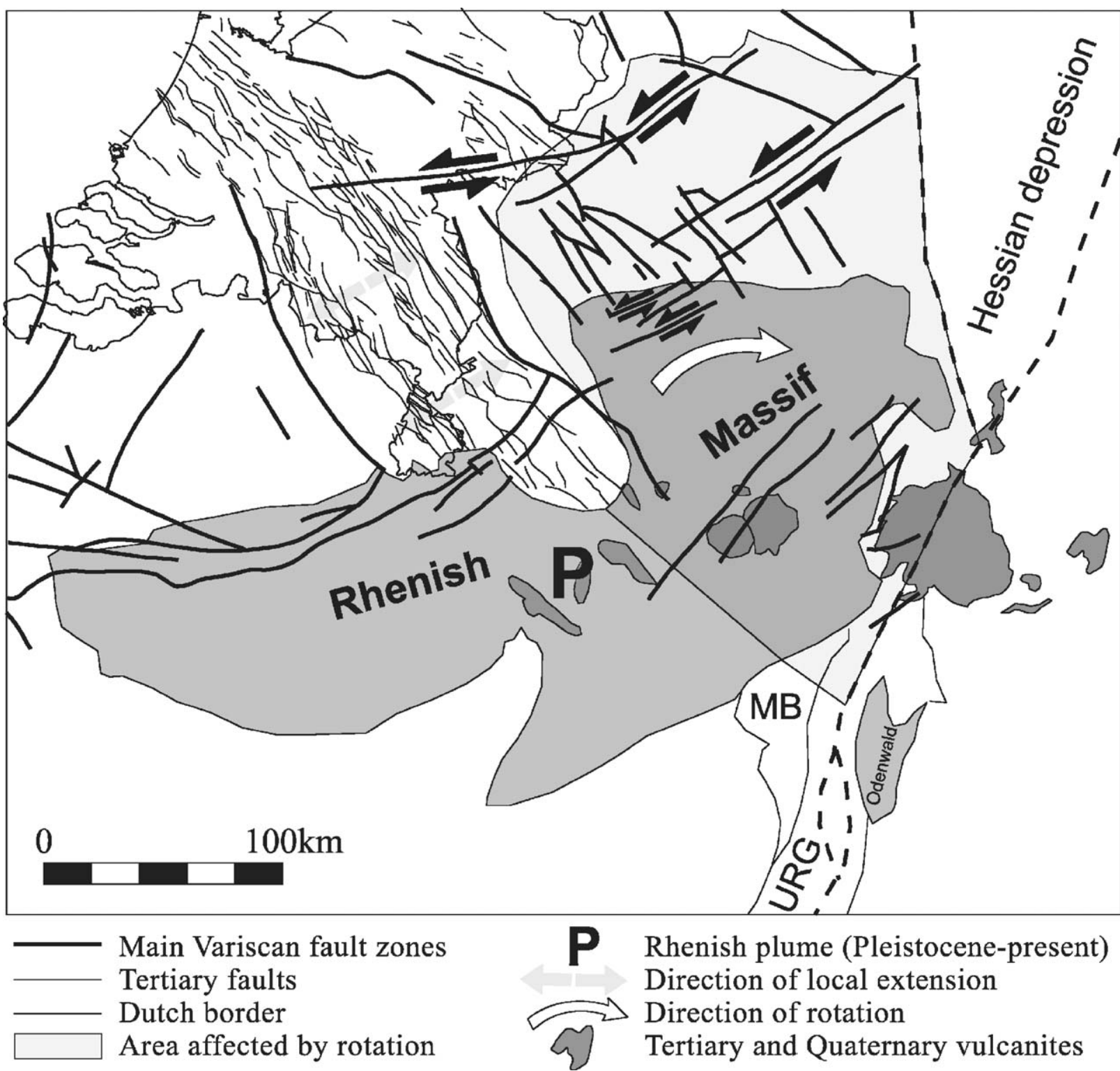

Fig. 10. Tectonic features of the Rhenish Massif area from the Late Oligocene onwards. (URG= Upper Rhine Graben, MB = Mainz Basin). Modified after Schreiber and Rotsch (1998). Variscan fault pattern is from Lokhorst (1998).

difference is not likely since, as it was shown earlier, during the Mesozoic the faults in both basins were already subjected to considerable amount of deformation, which should have led to a significant weakening of the faults in both the RVRS and the WNB. On the other hand as demonstrated by Tenthorey et al. (2003) faults can also heal due to mineralization. Therefore, during the Oligocene-Miocene tectonic quietness in the area of the WNB the faults might have become stronger relative to the RVRS where in the same period the primary faults were active. In reality both of the above mentioned processes might have played a role: in the WNB the fault became slightly stronger due to healing, while in the RVRS they became slightly weaker due to the renewed fault activity since the Late Oligocene.

\section{Acknowledgements}

This study was carried out in co-operation between the Vrije Universiteit, Amsterdam and TNO-NITG Dutch Geological Survey, Utrecht. The authors would like to thank Prof. J. Holbrook and J. Dirkzwager for their valuable work in reviewing the manuscript. Their remarks, which greatly contributed to the improvement of the paper, are highly appreciated. 


\section{References}

Angelier, J., 1984. Tectonic analysis of fault slip data. Journal of Geophysical Research 89, 5835-5848.

Bergerat, F., 1987. Stress field in the European platform at the time of Africa-Eurasia collision. Tectonics 6, 99-132.

Bott, M.H.P., 1959. The mechanics of oblique slip faulting. Geological Magazine 96, 109-117.

Camelbeeck, T., van Eck, T., 1994. The Roer Valley Graben earthquake of 13 April 1992 and its seismotectonic setting. Terra Nova 6, 291-300.

Camelbeeck, T., Van Eck, T., Pelzing, R., Ahorner, L., Loohuis, J., Haak, H.W., Hoang-Trong, P., Hollnack, D., 1994. The 1992 Roermond earthquake, the Netherlands, and its aftershocks. Geologie en Mijnbouw 73, 181-197.

De Lugt, I.R., Van Wees, J.D., Wong, Th.E., 2003. The tectonic evolution of the southern Dutch North Sea during the Paleogene: basin inversion in distinct pulses. Tectonophysics 373 (1-4), 141-159.

De Mulder, E.F.J., Geluk, M.C., Ritsema, I., Westerhoff, W.E., Wong, Th.E., 2003. De ondergrond van Nederland. Nederlandse Organisatie voor toegepast-natuurwetenschappelijk onderzoek TNO, p. 379.

Garcia-Castellanos, D., Cloetingh, S.A.P.L., Van Balen, R.T., 2000. Modelling the Middle Pleistocene uplift in the Ardennes-Rhenish Massif: thermo-mechanical weakening under the Eifel? Global and Planetary Change 27, 39-52.

Geluk, M.C., Duin, E.J.Th., Dusar, M., Rijkers, R.H.B., Van den Berg, M.W., Van Rooijen, P., 1994. Stratigraphy and tectonics of the Roer Valley Graben. Geologie en Mijnbouw 73, 129-141.

Gephart, J.W., Forsyth, D.W., 1984. An improved method for determining the regional stress tensor using earthquake focal mechanism data: application to the San Fernando earthquake sequence. Journal of Geophysical Research 89, 9305-9320.

Gras, R., Geluk, M.C., 1999. Late Cretaceous-Early Tertiary sedimentation and tectonic inversion in the southern Netherlands. Geologie en Mijnbouw 78, 1-19.

Groenewoud, W., Lorenz, G.K., Brouwer, F.J.J., Molendijk, R.E., 1991. Geodetic determination of recent land subsidence in The Netherlands. In: Johnson, A.I. (Ed.), Land Subsidence, vol. 200. IAHS Publ., pp. 463-471.

Haenel, R., 1983. Geothermal investigations in the Rhenish Shield. In: Fuchs, K., von Gehlen, K., Mälzer, H., Murawski, H., Semmel, A. (Eds.), Plateau Uplift, The Rhenish Massif, a Case History. Springer, Berlin, pp. 228-247.

Houtgast, R.F., Van Balen, R.T., 2000. Neotectonics of the Roer Valley Rift System, the Netherlands. Global and Planetary Change 27, 131-146.

Houtgast, R.F., Van Balen, R.T., Bouwer, L.M., Brand, G.B.M., Brijker, J.M., 2002. Late Quaternary activity of the Feldbiss Fault Zone, Roer Valley Rift System, the Netherlands, based on displaced fluvial terrace fragments. Tectonophysics 352, 295-315.

Huckenholz, H.G., 1983. Tertiary volcanism of the Hocheifel area. In: Fuchs, K., von Gehlen, K., Mälzer, H., Murawski, H., Semmel, A. (Eds.), Plateau Uplift, The Rhenish Massif, a Case History. Springer, Berlin, pp. 121-128.

Illies, J.H., Fuchs, K., 1983. Plateau Uplift of the Rhenish Massif - introductory remarks. In: Fuchs, K., von Gehlen, K., Mälzer, H., Murawski, H., Semmel, A. (Eds.), Plateau Uplift, The Rhenish Massif, a Case History. Springer, Berlin, pp. 1-8.

Kooi, H., Hettema, M., Cloetingh, S., 1991. Lithospheric dynamics and the rapid Pliocene-Quaternary subsidence phase in the southern north sea basin. Tectonophysics 192 (3-4), 245-259.

Kooi, H., Johnston, P., Lambeck, K., Smither, C., Molendijk, R., 1998. Geological causes of recent $(\sim 100 \mathrm{yr})$ vertical land movements in the Netherlands. Tectonophysics 299, 297-316.
Krantz, R.W., 1991. Measurements of friction coefficients and cohesion for faulting and fault reactivation in laboratory models using sand and sand mixtures. Tectonophysics 188, 203-207.

Langanaeker, V., 1998. The Campine Basin, stratigraphy, structural geology, coalification and hydrocarbon potential for the Devonian to Jurassic. Ph.D. Thesis Katholieke Universiteit Leuven, Leuven.

Letsch, W.J., Sissingh, W., 1983. Tertiary stratigraphy of The Netherlands. Geologie en Mijnbouw 62, 305-318.

Lippolt, H.J., 1983. Distribution of volcanic activity in space and time. In: Fuchs, K., von Gehlen, K., Mälzer, H., Murawski, H., Semmel, A. (Eds.), Plateau Uplift, The Rhenish Massif, a Case History. Springer, Berlin, pp. 112-120.

Liu, L., Zoback, M.D., 1997. Lithospheric strength and intraplate seismicity in the New Madrid seismic zone. Tectonics 16 (4), 585-595.

Lokhorst, A. (Ed.), 1998. The Northwest European gasatlas. Netherlands Institute of Applied Geosciences TNO (Haarlem): ISBN 9072869-60-5.

Michon, L., Van Balen, R.T. Characterisation and quantification of active faulting in the Roer Valley Rift System based on high precision Digital Elevation Models. Quaternary Science Reviews, this issue, doi:10.1016/j.quascirev.2003.11.009.

Michon, L., Van Balen, R.T., Merle, O., Pagnier, H., 2003. The Cenozoic evolution of the Roer Valley Rift System integrated at a European scale. Tectonophysics 367, 101-126.

Morris, A., Ferrill, D.A., Henderson, D.B., 1996. Slip-tendency analysis and fault reactivation. Geology 24 (3), 275-278.

Müller, G., Zoback, M.L., Fuchs, K., Mastin, L., Gregersen, S., Pavoni, N., Stephansson, O., Ljunggren, C., 1992. Regional patterns of tectonic stress in Europe. Journal of Geophysical Research 97, 11783-11803.

Plenefisch, T., Bonjer, K.P., 1997. The stress field in the Rhine Graben area inferred from earthquake focal mechanisms and estimation of frictional parameters. Tectonophysics 275, 71-97.

Prodehl, C., Mueller, St., Glahn, A., Gutscher, M., Haak, V., 1992. Lithospheric cross sections of the European Cenozoic rift system. Tectonophysics 208, 113-138.

Ramaekers, J.J.F., 1991. The Netherlands. In: Hurtig, E., Čermak, V., Haenel, R., Zui, V. (Eds.), Geothermal Atlas of Europe. Hermann Haack Verlagsgesellschaft mbH, Gotha.

Rijkers, R.H.B., Duin, E.J.Th., 1994. Crustal observations beneath the southern North Sea and their tectonic and geological implications. Tectonophysics 240, 215-224.

Ritter, J.R.R., Jordan, M., Christensen, U.R., Achauer, U., 2001. A mantle plume below the Eifel volcanic fields, Germany. Earth and Planetary Science Letters 186, 7-14.

Rondeel, H.E., Everaars, J.S.L., 1993. Spanning in noordoost Nederland, een breakoutanalyse. In: Eindrapport multidisciplinair onderzoek naar de relatie tussen gaswinning en aardbevingen in Noord-Nederland. Het Koninklijk Nederlands Meteorologisch Instituut (KNMI)

Schreiber, U., Rotsch, S., 1998. Cenozoic block rotation according to a conjugate shear system in central Europe-indications from palaeomagnetic measurements. Tectonophysics 299, 111-142.

Tenthorey, E., Cox, S.F., Todd, H.F., 2003. Evolution of strength recovery and permeability during fluid-rock reaction in experimental fault zones. Earth and Planetary Science Letters 206, $161-172$.

TNO-NITG, 1999. Geological Atlas of the Subsurface of the Netherlands: Explanation to mapsheet XV: Sittard-Maastricht, Utrecht, $127 \mathrm{pp}$.

TNO-NITG, 2001. Geological Atlas of the Subsurface of the Netherlands: Explanation to mapsheets XIII and XIV: Breda-Valkenswaard and Oss-Roermond, Utrecht, 149pp. 
TNO-NITG, 2002. Geological Atlas of the Subsurface of the Netherlands: Explanation to mapsheets VII and VIII: Noordwijk-Rotterdam and Amsterdam-Gorinchem. Utrecht, $135 \mathrm{pp}$.

TNO-NITG, 2003. Geological Atlas of the Subsurface of the Netherlands: Explanation to mapsheets XI and XII: Middelburg-Breskens and Roosendaal Terneuzen, Utrecht, 107pp.

Van Balen, R.T., Houtgast, R.F., Cloetingh, S.A.P.L. Neotectonics of the Netherlands. Quaternary Science Reviews, this issue, doi:10.1016/j.quascirev.2004.01.011.

Van Balen, R.T., Van Bergen, F., de Leeuw, C., Pagnier, H., Simmelink, H., Van Wees, J.D., Verweij, J.M., 2000. Modelling the hydrocarbon generation and migration in the West Netherlands Basin, the Netherlands. Geologie en Mijnbouw/Netherlands Journal of Geosciences 79 (1), 29-44.

Van Balen, R.T., Verweij, J.M., Van Wees, J.D., Simmelink, H., Van Bergen, F., Pagnier, H., 2002. Deep subsurface temperatures in the Roer Valley Graben and the Peelblock, the Netherlands - new results. Netherlands Journal of Geosciences/Geologie en Mijnbouw 81 (1), 19-26.

Van den Berg, M.W., 1994. Neotectonics of the Roer Valley rift system. Style and rate of crustal deformation inferred from syn-tectonic sedimentation. Geologie en Mijnbouw 73, $143-156$.

Van den Berg, M.W., Groenewoud, W., Lorenz, G.K., Lubbers, P.J., Brus, D.J., Kroonenberg, S.B., 1994. Patterns and velocities of recent crustal movements in the Dutch part of the Roer Valley rift system. Geologie en Mijnbouw 73, 157-168.

Van Wijhe, D.H., 1987. Structural evolution of inverted basins in the Dutch offshore. Tectonophysics 137, 171-219.

Wallace, R.E., 1951. Geometry of shearing stress and relation to faulting. Journal of Geology 59, 118-130.

Worum, G., Michlon, L., 2004. Implications on continuous structural inversion in the West Netherlands Basin for understanding controls on Palaeogene deformation of NW Europe. Journal of the Geological Society, London (in press).

Worum, G., Van Wees, J.D., Bada, G., Van Balen, R.T., Cloetingh, S.A.P.L., Pagnier, H., 2004. Slip tendency analysis as a tool to constrain fault reactivation: a numerical approach applied to 3-D fault models in the Roer Valley Rift System (Southeast Netherlands). Journal of Geophysical Research 109, B02401.

Zagwijn, W.H., 1989. The Netherlands during the Tertiary and the Quaternary: a case history of Coastal Lowland evolution. Geologie en Mijnbouw 68, 107-120.

Ziegler, P.A., 1990. Geological Atlas of Western and Central Europe, second and completely revised edition. Shell Int. Petr. Mij, The Hague.

Ziegler, P.A., 1994. Cenozoic rift system of western and central Europe: an overview. Geologie en Mijnbouw 73, 99-127.

Zijerveld, L., Stephenson, R., Cloetingh, S., Duin, E., Van den Berg, M.W., 1992. Subsidence analysis and modelling of the Roer Valley Graben (SE Netherlands). Tectonophysics 208, 159-171. 